\title{
ESTUDIO FARMACOCINÉTICO COMPARATIVO DE TRICLABENDAZOLE EN BOVINOS Y OVINOS
}

\author{
Formentini, e. A. ${ }^{1,9}$, Mestorino, N. 2,10, PesoA, J. M.,3, \\ LUCAS, M. ${ }^{4,10}$, Reggiardo, E. 5,9 , MARTI DIAZ, M.6,9,
}

ReutemanN, S. H. ${ }^{7,9}$ \& ERRECALDE, J. O.,10

\begin{abstract}
RESUMEN
Se llevó a cabo un estudio farmacocinético comparativo de triclabendazole (TCBZ) administrado por vía oral en bovinos y ovinos a la dosis de $10 \mathrm{mg} / \mathrm{kg}$. Para la realización de este experimento se utilizó una formulación comercial de TCBZ en forma de suspensión (Biofasiolex ${ }^{\circledR}$ Biogénesis S.A. Argentina). El orden y la velocidad a la que se produce la aparición del triclabendazole sulfóxido (TCBZSO) en la circulación sistémica fueron discriminados mediante la construcción de curvas individuales de fracción remanente del fármaco en el sitio de absorción en función del tiempo según el método de Wagner-Nelson. Los perfiles de concentraciones plasmáticas de sus metabolitos; TCBZSO y triclabendazole sulfona (TCBZSO2) fueron analizados mediante el método no compartimental. El orden del proceso cinético que rige la aparición del TCBZSO en plasma puede asimilarse a un proceso de orden cero, lo que se explica por el efecto reservorio del rumen que actúa a su vez como un sistema de liberación sostenida del TCBZ hacia el tracto digestivo posterior donde es absorbido. La evaluación de los parámetros farmacocinéticos pone de manifiesto un comportamiento farmacocinético diferente de TCBZSO y TCBZSO2 en bovinos y ovinos.

Palabras clave: triclabendazole, farmacocinética, absorción, bovinos, ovinos.
\end{abstract}

1.- Profesor Adjunto. Cátedra de Farmacología.

2.- Profesora Adjunta. Cátedra de Farmacología, Farmacotécnia y Terapéutica.

3, 4.- Auxiliares Diplomados. Cátedra de Farmacología, Farmacotécnia y Terapéutica.

5, 6, 7.- Alumnos de la Carrera de Medicina Veterinaria. Pasantes de asignatura. Farmacología.

8.- Profesor Titular. Cátedra de Farmacología, Farmacotécnia y Terapéutica.

9.- Facultad de Ciencias Veterinarias. Universidad Nacional del Litoral, Argentina.

10.- Facultad de Ciencias Veterinarias. Universidad Nacional de La Plata, Argentina.

Manuscrito recibido el 17 de diciembre de 2004 y aceptado para su publicación el 11 de abril de 2005. 


\section{SUMMARY}

\section{Comparative pharmacokinetic study of triclabendazole in cattle and sheep.}

A comparative pharmacokinetic study of triclabendazole (TCBZ) administered to cattle and sheep by oral route at the dose rate of $10 \mathrm{mg} / \mathrm{kg}$ was carried out. In the present experiment a commercial suspension of TCBZ (Biofasiolex ${ }^{\circledR}$ Biogénesis S.A. Argentina) was employed. The order and the rate of appearance of triclabendazole sulfoxide (TCBZSO) in the systemic circulation were discriminated by construction of individual curves of fraction of unabsorbed drug versus time according to Wagner-Nelson method. The plasma concentration profiles of their metabolites; TCBZSO and triclabendazole sulfone (TCBZSO2) were analyzed by means of the non-compartimental method. The order of the kinetic process that governs the appearance of the TCBZSO in plasma was better explained as zero order process, which is explained by the reservoir effect of the rumen which acts as a biologic slow release system of TCBZ to the posterior digestive tract where it is absorbed. The evaluation of the pharmacokinetic parameters shows a different pharmacokinetic behaviour of TCBZSO and TCBZSO2 between calves and sheep.

Key words: triclabendazole, pharmacokinetics, absorption, cattle, sheep. 